\title{
PERSPECTIVES ON THE DISCLOSURE OF THE LOCATION OF GOODS IN TERMS OF SECTION 97 OF THE NATIONAL CREDIT ACT 34 OF 2005
}

\author{
Stéfan Renke \\ BLC LLB LLM LLD \\ Associate Professor, University of Pretoria \\ Corlia van Heerden \\ BProc LLB LLM LLM LLD \\ Professor, University of Pretoria
}

\section{SUMMARY}

This article considers the provisions of section 97 of the National Credit Act 34 of 2005 (NCA), which are vitally important to credit providers and consumers alike and which entrench the obligation of a credit consumer who is subject to the Act to disclose to the credit provider the location of the goods financed under a credit agreement. Against a backdrop of similar provisions in the NCA's predecessors (the Hire-Purchase Act 36 of 1942 and the Credit Agreements Act 75 of 1980), the article seeks to evaluate what changes, if any, the NCA has brought in this context and to make appropriate recommendations relating to the scope and application of section 97 of the NCA. The discussion of the disclosure measures in the NCA and its predecessors is preceded by a brief overview of the Acts' fields of application insofar as the latter are relevant to the disclosure provisions. We conclude that the legislature needs to intervene and amend section 97 of the NCA (and regulation 34 which must be read with section 97), failing which these provisions will be a very limited tool in the hands of the credit provider to keep track of the goods that serve as security and their effectiveness will be greatly diminished.

INTRODUCTION

In South Africa, thousands of credit agreements are concluded annually to finance the sale or lease of motor vehicles. ${ }^{1}$ As such, vehicle asset financing is part of the core business of a number of credit providers. However, vehicle

According to Table 3.2 of the Consumer Credit Market Report $4^{\text {th }}$ Quarter Dec 2018 issued by the National Credit Regulator, the number of vehicle credit agreements for that quarter alone amounted to 182936 (see http://www.ncr.org.za/documents/CCMR/CCMR\% 202018Q4.pdf (accessed 2019-05-22). 
asset financing may be regarded as a business that inevitably gives rise to a number of risks, given that it is focused on security in the form of moveable goods that can be damaged in accidents or be stolen and moved across borders. Given the mobility of motor vehicles, defaulting consumers who cannot bring arrears on their accounts up to date often hide the financed vehicles to frustrate repossession thereof, unaware of the serious repercussions this may hold for them personally.

The purpose of this contribution is to consider the provisions of section 97 of the National Credit Act (NCA), ${ }^{2}$ which entrenches the obligation of the consumer to inform the credit provider of the location of goods financed under a credit agreement. The importance of these provisions is often overlooked in favour of more popular topics such as default notices or other enforcement procedures under the Act, but in the end, the issue of being able to locate goods that form the object of a secured credit agreement is pivotal to the enforcement process. It is accordingly necessary for credit providers to acquaint themselves appropriately with these provisions of the NCA so that they are aware of their remedies to safeguard access to their security. Consumers should also be aware that non-compliance with these provisions may result in serious consequences of a criminal nature. This contribution accordingly traces the evolution of the duty to disclose the location of financed goods in South African credit legislation in order to evaluate what changes the NCA has brought in this context and to make appropriate recommendations relating to the scope and application of section 97. Two legislative enactments aiming to regulate instalment transactions relating to movable goods preceded the NCA - to wit, the HirePurchase Act (HP Act) ${ }^{3}$ and the Credit Agreements Act (CAA). ${ }^{4}$ These Acts are discussed, followed by a discussion of the NCA and the authors' conclusions and recommendations.

\section{THE HP ACT AND THE CAA}

The first consumer credit enactment of national application in South Africa ${ }^{5}$ only applied to moneylending transactions and consequently instalment transactions relating to movable goods were not statutorily regulated. This resulted in the promulgation of the HP Act, ${ }^{6}$ which then functioned side by

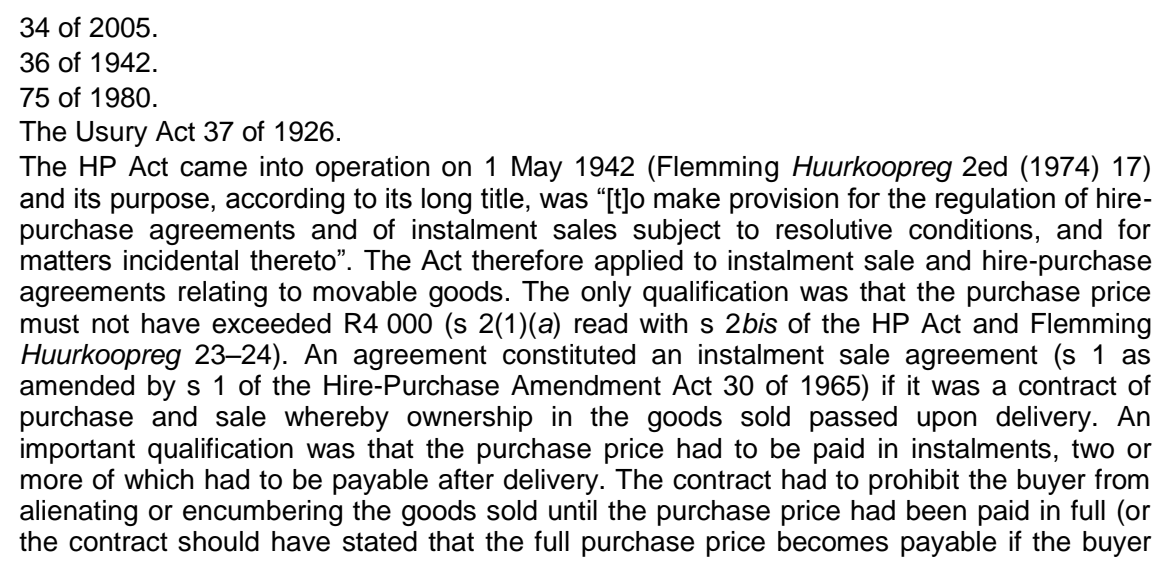

The HP Act came into operation on 1 May 1942 (Flemming Huurkoopreg 2ed (1974) 17) and its purpose, according to its long title, was "[t]o make provision for the regulation of hirepurchase agreements and of instalment sales subject to resolutive conditions, and for matters incidental thereto". The Act therefore applied to instalment sale and hire-purchase agreements relating to movable goods. The only qualification was that the purchase price must not have exceeded R4 000 (s 2(1)(a) read with s 2bis of the HP Act and Flemming Huurkoopreg 23-24). An agreement constituted an instalment sale agreement (s 1 as amended by $s 1$ of the Hire-Purchase Amendment Act 30 of 1965) if it was a contract of purchase and sale whereby ownership in the goods sold passed upon delivery. An important qualification was that the purchase price had to be paid in instalments, two or more of which had to be payable after delivery. The contract had to prohibit the buyer from alienating or encumbering the goods sold until the purchase price had been paid in full (or the contract should have stated that the full purchase price becomes payable if the buyer 
side with the 1926 Usury Act. $^{7}$ The CAA, which became effective on 2 March 1981, repealed the HP Act. ${ }^{8}$

In terms of both the HP Act and the CAA, the agreements that were subject to them had to be reduced to writing and signed by or on behalf of the parties. ${ }^{9}$ However, although unlike the CAA, ${ }^{10}$ the HP Act did not require the written agreement to state the business or residential addresses of the parties, ${ }^{11}$ neither Act explicitly required the parties to record the address where the goods subject to the agreement were kept. Nevertheless, the HP

alienates or encumbers the goods sold). Alternatively, the contract had to provide that the seller would be entitled to the return of the goods should the buyer fail to comply with one or more provisions thereof. The purpose of these clauses was to protect the seller since ownership of the goods passed to the buyer upon delivery. The hire-purchase agreement was defined as any agreement whereby goods are sold subject to the condition that the ownership in the goods does not pass merely by the transfer of possession of such goods. Again, in terms of the contract, the purchase price had to be paid in instalments, two or more of which had to be payable after such transfer. The hire-purchase agreement, in contrast to the instalment sale agreement, therefore contained an ownership reservation clause. The parties to an agreement that was subject to the HP Act were called the "seller" and the "buyer". See Flemming Huurkoopreg 19-22 for a discussion of these agreements and Renke An Evaluation of Debt Prevention Measures in Terms of the National Credit Act 34 of 2005 (doctoral thesis, University of Pretoria) 2012 337-339 for a discussion of the field of application of the HP Act.

7 And later with the Limitation and Disclosure of Finance Charges Act 73 of 1968 (LADOFCA), which repealed the 1926 Usury Act when it became effective on 1 April 1969. The LADOFCA was later renamed the Usury Act 73 of 1968 (Renke An Evaluation of Debt Prevention Measures 326-327).

8 The CAA then co-existed with the 1968 Usury Act until both Acts were repealed by the NCA. The contractual aspects of instalment transactions relating to movable goods were regulated by the CAA and the financial aspects of these contracts and of moneylending contracts by the Usury Act (Renke An Evaluation of Debt Prevention Measures 327). The CAA applied to credit transactions or leasing transactions. A credit transaction was a contract of purchase and sale of movable goods. In pursuance of the rules of the common law, the purchaser of the goods in terms of a credit transaction became the owner thereof when the goods were delivered to him or her. The instalment sale transaction was a species of the credit transaction, but what distinguished this transaction from other credit transactions was that the instalment sale transaction contained a clause that the purchaser would not become the owner of the goods merely by virtue of delivery to (this is a so-called ownership reservation clause, which usually reads that the purchaser will only become the owner of the goods once the final instalment has been paid) or use, possession or enjoyment of the goods by him/her. The parties alternatively agreed that the seller would be entitled to the return of the goods should the purchaser commit breach of contract. The leasing transaction was defined as a transaction whereby a lessor leased movable goods to a lessee. However, the contract was not a lease where the parties had agreed at the time of conclusion thereof that the lessee would become the owner of the goods at any time during the lease or on the expiry or termination thereof. A contract in terms of which the lessee would retain the possession, use or enjoyment of the goods after the expiry or termination of the lease likewise did not qualify as a lease. In terms of all the transactions to which the CAA applied, payment had to be effected in future. The parties to a credit agreement that was subject to the CAA were called the "credit grantor" and the "credit receiver". See s 2(1) read with s 1. See also Grové and Otto Basic Principles of Consumer Credit Law (2002) 1316 and Renke An Evaluation of Debt Prevention Measures 369-373 for a discussion of the field of application of the CAA.

$9 \quad S 4(1)$ of the HP Act and S 5(1)(a) of the CAA respectively.

$10 \mathrm{~S} 5(1)(b)$ of the CAA.

11 However, it can be assumed that the residential and business addresses of the parties would generally have been recorded in hire-purchase agreements as a matter of course, hence the obligation as stipulated in s 9(3) of the HP Act on the buyer to notify the seller of a change in his addresses (discussed later). 
Act and the CAA imposed an obligation on the parties to the agreement to furnish certain information to each other, including a pertinent obligation on the buyer or credit receiver to disclose information to the seller or credit grantor. In what follows, the provisions of section 8 of the CAA, which is largely a verbatim restatement of its predecessor (section 9(3) of the HP Act) is discussed, with an indication of the more important differences between the two sections. Although the CAA was the NCA's immediate predecessor, when discussing section 8 of the CAA (for purposes of assessing the NCA), heed must nevertheless be taken of comments relating to section $9(3)$ of the HP Act since the wording of sections 9(3) and 8 respectively corresponded to such a large extent. ${ }^{12}$ The same holds for the consequences of noncompliance with the section 8 (and section 9(3)) information duties.

Section 8 of the CAA made quite elaborate provision for the credit receiver's obligation to disclose the location of the goods and related aspects in the following terms: ${ }^{13}$

"Obligation of credit receiver to furnish certain information

8. (1) If at any time during the currency of any credit agreement the credit receiver or any other person who is or was in possession of any goods to which the credit agreement relates or who knows where such goods are, is requested in writing by or on behalf of the credit grantor or verbally or in writing by any deputy sheriff or messenger of the court, he shall, in accordance with the provisions of subsection (2), notify the person making the request-

(a) of his residential and business addresses;

(b) of the premises where such goods are normally kept, and of the name and address of the landlord, if any, of those premises;

(c) if those goods are no longer in his possession, of the name and address of the person in whose possession they are or to whom they were handed over, and of the place where they are kept.

(2) Any notice in terms of subsection (1) shall-

(a) in the event of a request by or on behalf of the credit grantor, be sent by registered mail to the person who made the request or, if that person agrees thereto, be given by furnishing verbal information to him, within seven days of the receipt of such request;

(b) in the event of a request made by any deputy sheriff or messenger of the court, be given forthwith by furnishing verbal information to him.

(3) If at any time during the currency of any credit agreement-

(a) the credit receiver changes his residential or business address;

12 For a discussion of s 9(3) of the HP Act, see Diemont and Aronstam The Law of Credit Agreements and Hire-Purchase in South Africa 5ed (1982) 150-153. Diemont and Aronstam, who discuss s 9(3) more comprehensively, remark that the same comments made in respect to s 9(3) apply to s 8 (Diemont and Aronstam The Law of Credit Agreements 165).

13 All italicised words in s 8 quoted below are the authors' emphasis. For a discussion of $s$ of the CAA, see De Jager Credit Agreements and Finance Charges (1981) 66-68; Flemming Krediettransaksies (1982) 292-294; Diemont and Aronstam The Law of Credit Agreements 165-166; Otto "Commentary" Credit Law Service (1991) par 35 and Grové and Otto Basic Principles 39-40. 
(b) the goods to which the credit agreement relates, or any part thereof, are removed from the place where the goods are ordinarily kept;

(c) the credit receiver loses or parts with the possession of the goods to which the credit agreement relates, or any part thereof, the credit receiver shall within 14 days notify by registered post the credit grantor-

(i) in a case contemplated in paragraph (a), of the new address;

(ii) in a case contemplated in paragraph $(b)$, of the premises to which the goods in question, or part thereof, were removed, and of the name and address of the landlord, if any, of such premises;

(iii) in a case contemplated in paragraph (c), of the name and address of the person in whose possession the goods in question are or to whom they were handed over, and of the place where they are kept."

The notable differences between section 8 of the CCA and section 9(3) of the HP Act are that in terms of the HP Act, ${ }^{14}$ (1) provision was made for the deputy sheriff or messenger of the court to request the information from the buyer verbally only (and not in writing) $;{ }^{15}$ (2) in both applicable subsubsections, ${ }^{16}$ if the goods were no longer in his or her possession, the buyer (or the person who had possession of the goods and from whom information was requested by the seller or a deputy sheriff or a messenger of the court) had to provide the name and address of the person in whose possession they were or to whom they were handed over or (and not "and") the place where they were; (3) the buyer lost or parted with the possession of the goods (and not "any part thereof"); ${ }^{17}$ and (4) the buyer had to "within fourteen days notify the seller in writing" (and not "the credit receiver shall within 14 days notify by registered post the credit grantor").

Failure to comply with the provisions of section 8 of the CAA constituted an offence and, upon conviction, the penalty was a fine not exceeding R5 000 or imprisonment not exceeding two years or both such fine and imprisonment. ${ }^{19}$

All words in italics are authors' emphasis.

S 9(3)(a) of the HP Act.

S 9(3)(a)(iii) and 9(3)(c)(iii) of the HP Act.

S 9(3)(c)(iii) of the HP Act.

$S 9(3)(c)$ of the HP Act.

See s 23 of the CAA, which was (to use the words of Van Zyl "Offences and Penalties" in Guide to the National Credit Act (2008) 16-1) an "all-encompassing penal provision". S 23 provided that "[a]ny person who contravenes or fails to comply with any provision of this Act, shall be guilty of an offence and liable upon conviction to..." (authors' emphasis). Failure to comply with the provisions of s 9(3) of the HP Act was also an offence. However, in the latter case, a fine not exceeding R100 or imprisonment for a period not exceeding six months could be imposed (s 9(4) of the HP Act). Unlike the CAA, the HP Act did not declare any contravention of the Act to be an offence. 


\section{Observations regarding section 8 of the CAA (and section 9(3) of the HP Act)}

Section 8 of the CAA notably imposed two distinct obligations on a credit receiver: the first was to provide information upon request, and the second was an automatic, non-prompted obligation to give notice of changed circumstances to the credit grantor. Diemont and Aronstam refer to the duties "[t]o provide information" and "[t]o give notice of change of address" but discuss the latter before the former. ${ }^{20}$ One may indeed surmise that it would have been more logical to have drafted section 8 in such a manner that the automatic obligation in section $8(3)$ preceded the obligation in section 8(1) to furnish information upon request; nevertheless, it is not a material issue and need not be further laboured over. We will discuss the duties in accordance with their order of appearance in section 8.

However, it is important to realise that the section 8(1) and section 8(3) duties existed "at any time during the currency of any credit agreement". The implications are twofold. First, in order for the section 8 duties to exist, a credit agreement that was subject to the CAA had to be involved ${ }^{21}$ and by necessary implication the Act therefore had to be applicable. This means inter alia that the CAA must have applied to the specific goods, and no exceptions to its field of application must have been applicable. ${ }^{22}$ Secondly, and provided then that the CAA was applicable in a specific instance, the section 8 duties remained with the credit receiver for as long as the agreement was in existence. According to Diemont and Aronstam, this was even the case where the buyer ${ }^{23}$ (or then the credit receiver) ${ }^{24}$ became the owner of the goods. ${ }^{25}$

The CAA Act did not require a specific recordal in the credit agreement if the address where the financed goods were kept differed from the credit receiver's residential or business address. However, one can assume that in most instances the goods would have been kept at either the credit receiver's residential address or at his or her business address, which explains the lack of a specific provision as aforesaid.

Upon written request by or on behalf of the credit grantor or upon verbal ${ }^{26}$ or written request by the deputy sheriff or the messenger of the court, the credit receiver had to notify the person making the request of the aspects mentioned. These included his or her residential and business addresses; the premises where the goods were normally kept, and the name and address of the landlord, if any, of those premises. ${ }^{27}$ If the goods were kept

\footnotetext{
Diemont and Aronstam The Law of Credit Agreements 165.

See fn 8 above in this respect.

See the sources mentioned in fn 8 above regarding the field of application of the CAA.

Under an instalment sale agreement in terms of the HP Act.

Under a credit transaction in terms of the CAA.

Diemont and Aronstam The Law of Credit Agreements 151.

The use of "verbal" and "verbally" in s 8 is not a good choice of words. "Verbal" or "verbally" could include written and oral words. The intention presumably was to mention an "oral" request or notifications only (Diemont and Aronstam The Law of Credit Agreements $152 \mathrm{fn}$ 206).

${ }^{27} \quad S 8(1)(a)$ and $(b)$ of the CAA respectively.
} 
on a leased premises, the credit grantor would have needed the detail of the landlord in order to notify the landlord of the fact that the specific goods were subject to a credit agreement governed by the CAA and thus did not form part of the invecta et illata that are subject to the landlord's tacit hypothec. ${ }^{28}$ It is important to note that, after 1993, section 2(1)(b) of the Security by Means of Movable Property Act ${ }^{29}$ provided that movables that were subject to an instalment sale agreement governed by the CAA were not subject to the landlord's tacit hypothec. The same did not hold true for movable goods leased in terms of a leasing transaction under the CAA and therefore it was possible for a landlord to exercise the hypothec in relation to such goods. ${ }^{30}$ Nevertheless, it would have been prudent for the credit grantor to be aware of the landlord's details in order to bring to his or her attention that the goods were subject to an instalment sale or leasing transaction governed by the CAA. This would have ensured that the goods did not come into the landlord's possession without the credit grantor's knowledge and be inadvertently sold by the former ${ }^{31}$ to recover arrear rent from the credit receiver.

If the goods were no longer in the possession of the credit receiver, the credit receiver had to furnish the name and address of the person in whose possession the goods were or to whom they were handed over, and of the place where they were kept. ${ }^{32}$ When drafting section $8(1)$, the legislature was thus also mindful that the goods might not have been kept at the address of a person referred to in section $8(1)(c)$, but that they could have been kept elsewhere. Section 8 therefore improved on section 9(3) of the HP Act, which used the conjunction "or" and not "and", seemingly giving a choice to the buyer or other person who no longer had possession of the goods regarding the information that had to be disclosed. ${ }^{34}$

Section $8(2)$ of the CAA, which dealt with the credit receiver's notification duty upon a request for information in terms of section 8(1), was couched in peremptory terms. The notification that had to be furnished in response to the request by or on behalf of the credit grantor had to be in writing and be sent by registered mail ${ }^{35}$ or it could be given verbally, if agreed to by the person making the request. Such notification (written or verbal) had to be furnished, within 7 days $^{36}$ of the receipt of the request, to the person making

28 For more detail in connection with this hypothec, see Nagel, Barnard, Boraine, Delport, Kern, Lötz, Otto, Papadopoulos, Prozesky-Kuschke, Roestoff, Van Eck and Van Jaarsveld Commercial Law 5ed (2015) 425.

2957 of 1993, assented to on 29 April 1993.

30 See also Diemont and Aronstam The Law of Credit Agreements 151 fn 201.

Who was unaware of the credit grantor's ownership in the goods.

$S 8(1)(c)$ of the CAA, authors' emphasis.

S 9(3)(a)(iii) of the HP Act. See heading 2 above.

34 See also Diemont and Aronstam The Law of Credit Agreements 152 who remark that "the [credit receiver] is given the alternative choice of informing the [credit grantor] of the place at which the goods are to be found".

35 The registered post requirement was to ensure there was proof that the written notification had indeed been sent and of the date on which it had been sent, so as to avoid disputes regarding the dispatch of the notification.

36 "Days" means calendar days and the statutory method of computation of time, set out in s 4 of the Interpretation Act 33 of 1957, was used to calculate the period of seven days. In terms of this method, "time is calculated exclusively of the first day and inclusively of the 
it. ${ }^{37}$ According to Diemont and Aronstam, this could have meant that the notice had to "reach the nominated address within the seven-day period". ${ }^{38}$ In the event that the request was made by the sheriff or messenger of the court, the information had to be given verbally and forthwith. ${ }^{39}$ Note that the obligation to furnish the information mentioned in section 8(1), which arose only once the contemplated request was made, applied not only to a credit receiver but extended to "any other person" who was or had been in possession of any goods to which the credit agreement related or who knew where such goods were.

The second obligation imposed by section 8 did not arise as a result of a request as contemplated in section $8(1)$. This obligation was directed only at the credit receiver and was automatically triggered by the happening of one or more of the events contemplated in section $8(3)(a)-(c)$. These events were the following: the credit receiver changed his or her business or residential address; the goods or part thereof were removed from the place where they were ordinarily kept; or the credit receiver lost or parted with the possession of the goods or any part thereof. Once any of these circumstances were present, the credit receiver had an obligation (automatically and without being prompted by the credit grantor) to give notice to the credit grantor. ${ }^{40}$

What would have constituted a change of address depended on the circumstances of each case. ${ }^{41}$ The interesting question arose whether a temporary removal ${ }^{42}$ of the goods ${ }^{43}$ from the place where they were ordinarily kept would have triggered the section 8(3) duty to furnish information. According to Diemont and Aronstam, the position was not clear. ${ }^{44}$ However, they submit that "[t]o remove' ... implies more than just temporary displacement". ${ }^{45}$ With reference to Flemming, ${ }^{46}$ the aforementioned authors submit that section 8(3) should be interpreted in the light of the mischief it attempted to prevent. The general aim was to ensure "that the [credit receiver] does not fraudulently dispose of the goods, and that the goods will not, without the [credit grantor's] knowledge, come into the hands of a third person" ${ }^{47}$ If the section were interpreted in this light, it

Iast, except where the last day is a Sunday or public holiday, in which case an extra day is included in the period" (Diemont and Aronstam The Law of Credit Agreements 146).

$37 \quad S 8(2)(a)$ of the CAA.

38 Diemont and Aronstam The Law of Credit Agreements 152 fn 207 read with fn 176 at 146. The authors based their argument on an interpretation of $s 7$ of the Interpretation Act 33 of 1957.

$39 \mathrm{~S} 8(2)(b)$ of the CAA.

40 The common law does not impose a duty on a debtor on credit to notify the creditor of any change of address (Diemont and Aronstam The Law of Credit Agreements 150).

41 Diemont and Aronstam The Law of Credit Agreements 151.

42 E.g., a buyer (credit receiver) who takes the goods on holiday or for repair.

43 Or part thereof.

44 Diemont and Aronstam The Law of Credit Agreements 151.

45 Diemont and Aronstam The Law of Credit Agreements 151 fn 202.

46 Flemming Huurkoopreg 117-118.

47 Such as a lessor in terms of his or her hypothec (Diemont and Aronstam The Law of Credit Agreements $151 \mathrm{fn} 201$ ). 
would not have been necessary to inform the credit grantor of a temporary removal, ${ }^{48}$ "since the mischief [would] not [have] arise[n] in such a case".

The credit grantor had to be notified in writing by registered post ${ }^{50}$ of any of the aforementioned changes within 14 days $^{51}$ of the date on which the relevant change occurred. A mere telephone call or other oral communication would therefore not have constituted compliance with the section 8(3) notification requirement. Depending on the change or changes involved, the credit grantor had to be notified of: the new address; the premises to which the goods (or part thereof) were removed and the name and address of the landlord of the premises, if any; and/or the name and address of the person who was in possession of the goods or to whom the goods were handed over; and ${ }^{52}$ the place where the goods were kept. ${ }^{53}$ There was no specific duty placed on the credit receiver to give a residential or business address. ${ }^{54}$

Usually a failure to comply with the provisions of the CAA would not have constituted a breach of contract, unless the credit grantor had so stipulated in the contract. ${ }^{55}$ The credit grantor was also free to stipulate in the credit agreement that notice had to be given prior to any contemplated change of address or removal of the goods or even that the goods could only be removed with the credit grantor's prior consent. ${ }^{56}$

Unlike the HP Act, which created certain specified offences for noncompliance with certain of the Act's provisions (such as section 9(3)), ${ }^{57}$ the legislature took a more serious approach to non-compliance with the provisions of the CAA. Accordingly, section 23 made contravention of any provision of the CAA an offence and did not distinguish between "prohibited conduct" and offences. ${ }^{58}$ The same was true for a contravention of the provisions of section 8 . It must be noted that a credit receiver and/or third party could have been prosecuted for a contravention of section 8 - the former for a contravention of section 8(1), read with section 8(2), section $8(3)^{59}$ or of both; and the latter for a contravention of section $8(1)$, read with section $8(2)$. Naturally, before any charge could be laid against a credit

48 On holiday, on a picnic, for repairs.

49 Diemont and Aronstam The Law of Credit Agreements $151 \mathrm{fn} 201$.

See authors' comment in fn 35 above.

51 The comments made above in respect to the meaning and calculation of "within 7 days" also apply in this instance.

52 As was mentioned above (under heading 2), s $9(3)(c)$ of the HP Act used the conjunction "or" and not "and". See above for authors' comments in this regard.

$53 \mathrm{~S} 8(3)(c)(\mathrm{i})$-(iii) of the CAA.

54 Diemont and Aronstam The Law of Credit Agreements 152.

55 Ibid.

56 Ibid.

57 See s 9(4) mentioned under heading 2 fn 19 above.

58 See Grové and Otto Basic Principles 56, who criticise the "undesirable and sweeping criminalisation of the private law" and contend that the legislature in the CAA should have been much more selective in the creation of offences. They also remark that a credit receiver should have had adequate civil-law remedies to make it worthwhile to enforce his or her rights.

59 E.g., see Struwig NO v Marais 1999 (2) SA 214 (O), where the credit receiver was found guilty of an offence in terms of $s 23$ of the CAA for non-compliance with the provisions of $s$ $8(3)(c)$ read with $s,(3)(c)($ iii) of the CAA. 
receiver and/or third party, the provisions of section 8 had to be complied with. For instance, a premature charge would not have been accommodated by the police and/or prosecuting authorities.

One has to bear in mind that where a credit receiver failed automatically to notify the credit grantor that he or she had changed address or otherwise as required by section $8(3)$, the credit grantor would generally not have been aware that such change occurred until such time as it attempted to contact the credit receiver or enforce the credit agreement and was then met with no response. In such instances, the credit grantor would then, in practice, often send a representative (referred to as a "tracer") to trace the credit receiver; or if the credit receiver still lived at and/or worked at the recorded addresses, but the goods were not on either of the said premises, the representative would pay the credit receiver a visit to enquire about the location of the goods. Where the credit receiver had moved from either or both his residential and business addresses, the credit grantor would generally be unaware thereof until such time as the tracer made enquiries or the sheriff attended at the address recorded in the credit agreement with a court order authorising repossession of the goods. Where the credit grantor obtained information from the tracer or sheriff indicating that the credit receiver and/or the goods were not at the addresses as recorded in the agreement, the credit grantor would then in writing request the credit receiver to disclose the information as stated in section 8(1). Very often, if the goods were no longer on the recorded premises, but the credit receiver or any other person was present on the premises, or the credit grantor knew where to find the credit receiver, the sheriff was instructed to put the section $8(1)$ request to the credit receiver (or such other person) because in the latter instance, although it was more costly, the credit receiver had to notify the sheriff forthwith of the information sought. ${ }^{60}$ Thus, not only did the presence of the sheriff serve to alert the credit receiver to the seriousness of the request but the goods could be located more quickly, or criminal charges could also be pressed more quickly if the credit receiver failed to give proper notification of the information that he or she was required to provide in terms of section $8(1)$. Using the sheriff to extract the information was thus generally a quicker measure than if the credit grantor merely made a written request to which the credit receiver then had seven days to reply. However, this seven-day time period could arguably also be counterproductive as it alerted the credit receiver to the fact that the credit grantor wanted to repossess the goods. In the case of a mala fide credit receiver, it thus gave him or her some opportunity to hide the vehicle or other goods at another place or take it across the border into another African country. ${ }^{61}$

The purpose of section 8 of the $C A A^{62}$ was clearly to enable a credit grantor to know at all times where to find the credit receiver and also where to find the financed goods - information that was crucial, especially when the credit receiver defaulted on the credit agreement, or unlawfully transferred

60 In some instances, the credit grantor may have been tipped off in advance (without first sending a tracer to the premises) that the goods were not at the recorded premises, in which event time would not be wasted and the sheriff would be instructed to make an immediate $s$ (1) request for information regarding the whereabouts of the goods.

61 This has been experienced by the one writer in practice.

62 And of $s$ 9(3) of the HP Act. 
possession of the goods to a third party, and the credit grantor wanted to enforce the agreement and repossess its security (the financed goods).

\section{The NCA}

The NCA, which became fully effective on 1 June $2007,{ }^{63}$ repealed the CAA ${ }^{64}$ The NCA, unlike its predecessors, does not contain a provision requiring writing and signature as specific formalities in relation to credit agreements that are subject to the Act. ${ }^{65}$ However, in terms of section 93(1) of the NCA, the credit provider is obliged to deliver to the consumer a copy of its credit agreement, with the implication that all credit agreements subject to the NCA in any event have to be reduced to writing. In the case of a small credit agreement, the credit agreement must set out the consumer's personal particulars, including his physical address. ${ }^{66}$ However, nowhere does the NCA require the parties to state their residential and/or business addresses and/or the premises where the goods are kept.

Importantly, the NCA, like its predecessors, does contain provisions regarding the disclosure of the location of financed goods by a consumer

63 The NCA was put into operation on 1 June 2006, 1 September 2006 and 1 June 2007 (Proc 22 in GG 28824 of 11 May 2006). The NCA has a wide field of application. It applies to the following credit agreements: credit facilities, credit transactions, credit guarantees or a combination of transactions. In order for any agreement to qualify as a credit agreement for the purposes of the Act, two elements have to be present. First, the consumer's obligation to pay the credit granted or to repay an amount borrowed (or part thereof) to the credit provider is either deferred, or provision is made for some form of prepayment. Secondly, with the exception of the "mortgage agreement" and the "secured loan", defined in s 1, there is a fee, charge or interest imposed with respect to the deferred payment (or repayment) or a discount is granted where prepayments are effected. In summary, if the transactions to which the NCA applies as well as the exclusions from its scope of application are considered, it can be concluded that, except for the few transactions specifically excluded from its ambit, the Act applies to all credit agreements whether small or large and irrespective of their form, the type of movable goods (or services) or the amount of money involved. The NCA also applies to credit agreements concluded in respect of immovable property, whether the property is sold and bought on credit or serves as security for the payment or repayment of credit. The proviso is that the particular credit agreement must have been concluded at arm's length and in South Africa or has an effect in South Africa. The parties to a credit agreement that is subject to the NCA are called the "consumer" and the "credit provider". See ss 4-11 of the NCA. See also Kelly-Louw (assisted by Stoop) Consumer Credit Regulation in South Africa (2012) ch 2; Van Zyl "The Scope of Application of the National Credit Act" and Otto "Types of Credit Agreement" in Guide to the National Credit Act (2008) chs 4 and 8 respectively and Renke An Evaluation of Debt Prevention Measures 383-403 for a discussion of the NCA's field of application.

64 And the Usury Act 73 of 1968 (in terms of s 172(4), which became effective on 1 Jun 2006).

65 See Renke and Kinnear "Formaliteitsvoorskrifte (of gebrek daaraan) ingevolge die Nasionale Kredietwet 34 van 2005" 201376 THRHR 665ff.

66 S 93(2), read with reg 30 of the Regulations made in terms of the NCA (GN R489 in GG 28864 of 31 May 2006) (the NCA Regulations), read with Form 20.2. However, in the case of an intermediate or large credit agreement, the personal particulars of the consumer are not required to be set out in the agreement (s 93(3), read with reg 31 of the NCA Regulations). This was probably an oversight by the legislature. See ss 7(1)(b) and 9(2), (3) and (4) respectively, read with the Determination of Thresholds (GN 713 in GG 28893 of 1 June 2006) and Otto Guide to the National Credit Act par 8.7 for "small", "intermediate" and "large" credit agreements. 
who is subject to the Act - namely, section 97, read with regulation 34 of the NCA Regulations. Section 97 provides as follows: ${ }^{67}$

"97. Consumer must disclose location of goods-

(1) This section applies to a credit agreement if-

(a) it concerns any goods, and the consumer at any time during the agreement has or had possession of those goods; and

(b) in terms of the agreement-

(i) the title to those goods has not passed to the consumer; or

(ii) the credit provider has a right to take possession of the goods irrespective of whether they are owned by the consumer or another person.

(2) Until the termination of an agreement to which this section applies, the consumer must inform the credit provider, in the prescribed time, manner and form, of any change concerning-

(a) the consumer's residential or business address;

(b) the address of the premises in which any goods that are subject to the agreement are ordinarily kept; and

(c) the name and address of any other person to whom possession of the goods has been transferred.

(3) On request by the credit provider, a deputy sheriff or messenger of the court, the consumer must inform that person, in the prescribed manner and form, of the address of the premises where the goods are ordinarily kept and the name and address of the landlord, if any, of those premises.

(4) If at the time of a request under subsection (3) the consumer is no longer in possession of the goods that are subject to the agreement, the consumer must provide the name and address of the person to whom possession of those goods has been transferred.

(5) A consumer who knowingly-

(a) provides false or misleading information to a credit provider, deputy sheriff or messenger of the court under this section; or

(b) acts in a manner contrary to this section with intent to frustrate or impede a credit provider exercising rights under this Act or a credit agreement,

is guilty of an offence."

Regulation 34 of the NCA Regulations, in turn, provides the following: ${ }^{68}$

“34. Disclosure of location of goods-

(1) In respect of a credit agreement to which section 97 of the Act applies the consumer must disclose any changes concerning the matters listed in section $97(2)$ in writing to the credit provider within 10 business days after the change and deliver it to the credit provider;

(2) When disclosing such a change, the consumer must complete Form 24 or provide the following information to the credit provider:

(a) name of the consumer;

(b) a reference number or account number provided by the credit provider;

(c) the date upon which the change was effective; and

67 The words in italics are authors' emphasis. For a discussion of s 97 of the NCA, see KellyLouw (assisted by Stoop) Consumer Credit Regulation 215-216, 510 and 512.

68 The words in italics are the authors' emphasis. 
(d) the date of the disclosure.

(3) On request by the credit provider, messenger of the court or the deputy sheriff, as contemplated in section 97(3), the consumer-

(a) must provide the information in writing by completing Form 25,

(b) may otherwise provide the information orally."

Notably, the NCA does not have a general penal provision similar to section 23 of the CAA. ${ }^{69}$ Thus, not all contraventions of all the sections of the NCA constitute offences. In certain limited instances in terms of the Act, an offence is created specifically in a section - for instance, in section 97 . There are also a few sections in Part B of Chapter 8 of the NCA that deal particularly with offences relating to the enforcement of the NCA. Section 161 provides generally that any person convicted of an offence in terms of the $\mathrm{NCA},{ }^{70}$ is liable to a fine or to imprisonment for a period not exceeding 12 months, or to both a fine and imprisonment. ${ }^{71}$

\section{Observations regarding section 97 of the NCA, read with regulation 34 of the NCA Regulations}

At first glance, section 97 appears to be well structured. Its scope of application indicates that it only applies to credit agreements where the consumer is/was in possession of goods to which the agreement relates and ${ }^{72}$ either ownership of the goods is reserved by the credit provider or the credit provider has a contractual right to take repossession of those goods, irrespective of whether they are owned by the consumer or another person. ${ }^{73}$ The only two credit agreements that adhere to the section 97(1) requirements in order for section 97 to find application are an instalment agreement and a lease. ${ }^{74} \mathrm{An}$ instalment agreement means a credit sale of movable goods under circumstances where possession and use of the property is transferred to the consumer immediately. The contract, however, either contains an ownership reservation clause in terms of which the consumer becomes the owner of the goods only once the contract is fully complied with ${ }^{75}$ or it allows ownership to pass to the consumer immediately, subject to a right of the credit provider to repossess the goods if the consumer fails to satisfy all his or her financial obligations under the agreement. $^{76}$ In terms of a leasing transaction of movable property that is

69 See also Van Zyl Guide to the National Credit Act 16-1.

70 With the exception of $\mathrm{s} 160(1)$, which concerns a contravention of or failure to comply with an order of the National Consumer Tribunal (the Tribunal), for which a more severe penalty is provided.

71 Note that the penalties for offences must be distinguished from administrative fines that may be imposed by the Tribunal in terms of $s 151$ of the NCA. See Van Zyl "The Effects of NonCompliance" in Guide to the National Credit Act (2008) 17-1.

72 Authors' emphasis.

$73 \mathrm{~S} 97(1)$ of the NCA.

74 Both these credit transactions are defined in S 1 of the NCA. S 97 does not apply to incidental credit agreements, nor to a credit agreement in terms whereof goods are provided to the consumer and where payment is deferred (s 5(1) of the NCA).

75 E.g., upon payment of the final instalment by the consumer.

76 See, in connection with the transfer of ownership options, Renke and Pillay "The National Credit Act 34 of 2005: The Passing of Ownership of the Thing Sold in Terms of an 
subject to the NCA, at the end of the term of the agreement, ownership of the property either passes to the consumer absolutely or upon satisfaction of specific conditions set out in the agreement. ${ }^{77}$ In other words, until the consumer becomes the owner of the leased goods at the expiration of the lease, the "title to those goods has not passed to the consumer". ${ }^{78}$

The sequencing of the obligations in section 97, to inform the credit provider (without first being requested to do so) of any changes followed by the furnishing of information upon request, is more logical than was the case under section $8 .^{79}$ However, in terms of the NCA, the consumer, in order to become acquainted with his or her obligations under section 97, must not only consult the said section, but also regulation 34 and Form 24 and/or Form 25.

Section 97(2) makes it clear that the consumer is under a continuous and unprompted ${ }^{80}$ obligation $^{81}$ for the duration of the agreement ${ }^{82}$ to inform the credit provider of changes in respect of the consumer's residential or business address; the address of the premises where the goods are ordinarily kept; ${ }^{83}$ and the name and address of any other person to whom possession of the goods has been transferred. ${ }^{84}$ When section $97(2)(a)$ to (c) of the NCA is compared with its counterpart in the NCA's immediate predecessor, section $8(3)(a)$ to $(c)$ of the CAA, ${ }^{85}$ substantial differences immediately become apparent. Section 97 itself only imposes a duty on the consumer to inform the credit provider of the specific change or changes for instance, a change of residential or business address, without pertinently imposing a duty, for instance, to state the new address. It should therefore suffice for the consumer to merely state: "Take note, my address has changed". However, section $97(2)(a)$ to (c) has to be read with regulation $34(1)$ and Form 24 or regulation 34(2)(a) to (d) of the NCA Regulations. In terms of Form 24, the consumer must notify the credit provider that "My residential/business ${ }^{* 86}$ address has changed to \{insert address\} ..." Regulation 34(2)(a) to (d), which serves as an alternative to Form 24, does not impose a duty to inform the credit provider of the new address. It only requires disclosure of the name of the consumer, a reference or account number, the date upon which the change was effective and the date of the disclosure. Section $8(3)(a)$ of the CAA imposed a duty on the credit receiver

Instalment Agreement" 200871 THRHR 641ff. See also the discussion by Otto Guide to the National Credit Act par 8.2.3.4.

77 The situation was different under the CAA. In terms of that Act's definition of a leasing transaction in $s 1$, if the goods automatically became the property of the lessee at the expiration of the lease, the transaction was not regarded as a lease.

78 The words used in s 97(1)(b)(i) of the NCA

79 See heading 21 above.

80 Thus out of his own accord and without the information being requested by the credit provider, the deputy sheriff or a messenger of the court.

81 S 97(2) of the NCA states that the consumer "must" inform the credit provider

82 In other words, until the agreement is terminated for whatever reason, e.g. performance or cancellation as a result of breach of contract.

83 This would refer to the address as agreed by the parties in the credit agreement or subsequently changed in accordance with s 96(2) of the NCA.

$84 \mathrm{~S} 97(2)(a)-(c)$ of the NCA.

85 See headings 2 and 21 above.

86 "(*delete whichever is not applicable)". 
to inform the credit grantor not only of an address change but also of the new address.

Similar comments pertain to section $97(2)(b)$ of the NCA, which, in contrast to section $8(3)(b)$ of the CAA, once again has to be read with regulation $34(1)$ and Form 24 or regulation $34(2)(a)$ to (d) of the NCA Regulations to form the full picture. And it is again Form 24, and not section $97(2)(b)$, that "imposes the obligation" to inform the credit provider of the address of the premises where "[t]he goods... is/are now situated", after the change. However, regulation 34(2)(a) to (d), if used as an alternative to Form 24, does not impose a similar obligation.

The provisions of section $97(2)(b)$ of the NCA are notably different from those in section $8(3)(b)$ of the CAA, the latter requiring the credit receiver to inform the credit grantor of: (1) the removal of the goods, or any part thereof, from the place where the goods were ordinarily kept; (2) the new premises to which the goods (or part thereof) had been removed; and (3) the name and address of the landlord, if any, of the premises. The latter requirement is remarkably absent from section $97(2)(b)$.

Now, consideration turns to a comparison of section 97(2)(c) of the NCA with section $8(3)(c)$ of the CAA. The NCA provision, read on its own, imposes only an obligation to inform of a change in the name and address of any other person to whom possession of the goods has been transferred. What does this mean? Does it presuppose that the credit provider has previously been informed of the name and address of any other person (other than the consumer) to whom possession of the goods has been transferred, and that the name and address of that other person has now changed? When Form 24 is brought into the picture, the credit provider must be informed of the full names and physical address of the person who now has possession of the goods, after the change.$^{87}$ Regulation $34(2)(a)$ to (d) omits the latter requirement. Section $8(3)(c)$ of the CAA also required the credit receiver to inform the credit grantor of the name and address of the person in whose possession the goods (or part thereof) were. Alternatively, and this is absent from section $97(2)(c)$ of the NCA read with its regulations and Forms, the credit receiver could have informed the credit grantor of the details of the person to whom the goods were handed over. Additionally, in terms of section $8(3)(c)$ of the CAA, the credit grantor had also to be informed of the place where the goods were kept, which is not required in terms of section $97(2)(c)$ of the NCA, its regulations or its Forms. These are not the only differences between the subsection currently applicable and its predecessor. Section $8(3)(c)$ of the CAA imposed a duty on the credit receiver to notify the credit grantor of the aforementioned aspects where or if the credit receiver had lost or parted with possession of the goods (or part thereof) to which the credit agreement related. Section $97(2)(c)$ of the NCA does not similarly qualify when the duty to notify arises.

Although the obligation to provide unprompted information in terms of section $97(2)(a)$ to $(c)$ of the NCA thus seems to mirror the obligation that was previously imposed under section $8(3)(a)$ to $(c)$ of the CAA, the

87 "Physical address" can be either the person's residential or business address but is not necessarily the address where the goods are kept. 
differences between them are more than semantic. We submit that one, concise provision in the NCA itself (similar to section 8(3) of the CAA) would have been preferable to provisions that are scattered over the Act, the NCA Regulations and the Forms. Linked to this, it is submitted that the practice of elaborating on a party's duties in a Form attached to the NCA is questionable.

Legislative attention is needed to resolve the discrepancies between the content of Form 24 and the information that must alternatively be provided in terms of regulation 34(2)(a) to (d) of the NCA Regulations. The regulation 34(2) information is totally deficient and does not address the consumer's section 97(2) obligation at all. The consumer should be required only to complete Form 24 and the option of providing the information in terms of regulation 34(2) should be removed or the latter option should be augmented to bring it into line with the contents of Form 24.

The relevance of indicating the name and address of the landlord, if applicable, was indicated above. ${ }^{88}$ Not to have made it obligatory for the consumer to mention a landlord's details, where applicable, is therefore a lacuna in the NCA.

In particular, section $97(2)(c)$ of the NCA, when compared to section $8(3)(c)$ of the CAA, is poorly drafted. The exact meaning of the subsection, when read on its own, is unclear. Furthermore, a person in whose possession the goods are, and a person to whom the goods were handed over, could be different persons. The provisions of the NCA, like its predecessor, should therefore also provide for disclosure of the details of the person to whom the goods were handed over.

A lacuna was further created by the omission in section $97(2)(c)$ of the NCA of an obligation also to inform the credit provider of the place where the goods are kept. As indicated above, ${ }^{89}$ the goods may not always be kept at the address of the person in whose possession the goods are (or of the person to whom the goods were handed over).

Finally, the failure to qualify in section $97(2)(c)$ of the NCA when the duty to notify arises is material. Merely requiring a consumer to inform a credit provider of any change in the name and address of any person to whom possession of the goods has been transferred does not address the case where the consumer has lost the goods. The credit provider should also in the latter instance be informed of the "change".

The prescribed manner, form and time of notification in terms of section $97(2)$, read with regulation $34(1)$ of the NCA, is mostly similar to the manner of notification provided for in section 8(3) of the CAA. A written notice is/was required in both instances and ten business days ${ }^{90}$ and 14 days $^{91}$ will usually amount to the same time period within which the

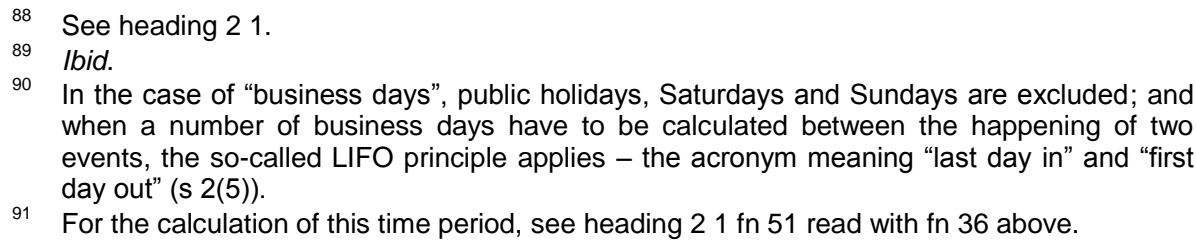

91 For the calculation of this time period, see heading $21 \mathrm{fn} 51$ read with fn 36 above. 
respective notices in terms of section 97(2), read with regulation 34(1) of the NCA, and in terms of section 8(3) of the CAA has or had to be delivered. Regulation 34(1) of the NCA requires that the consumer "deliver" the written notification to the credit provider. We submit that the definition of "delivered" in regulation 1 of the NCA Regulations is pertinent, ${ }^{92}$ meaning that the notice can be sent by hand, fax, e-mail or registered mail. ${ }^{93}$ The NCA Regulations accordingly provide for more options of delivery than did section 8(3) of the CAA, which only provided for delivery by registered post.

Section $97(3)$ and (4) of the NCA must be read together; they are the counterpart of the "duty to provide information" in terms of section 8(1), read with section $8(2)$, of the $C A A,{ }^{94}$ which is prompted or triggered by a request. However, section 97(3) and (4) must be read with regulation 34(3) of the NCA and, in some instances, Form 25. Where section 8(1) of the CAA imposed a duty to inform upon request, and stated the information that had to be disclosed upon such request, the duty to inform upon request in the NCA is imposed in section 97(3) and the information that must be disclosed in section 97(3) and (4). Section 8(2) of the CAA regulated the manner and timing of the notification of the requested information, whereas, in the NCA, the manner and form of the notification is prescribed in regulation 34(3), read with Form 25 - the latter, where applicable.

Be that as it may, the NCA, like its predecessor, imposes an obligation to furnish certain information upon request. The consumer must provide the address of the premises where the goods are ordinarily kept and the name and address of the landlord, if any, of such premises. ${ }^{95}$ Furthermore, if the consumer is no longer in possession of the goods, the consumer must provide the name and address of the person to whom possession of the goods has been transferred. ${ }^{96}$ Although section $97(3)$ and (4) of the NCA, read with regulation $34(3)$ and Form 25, if used by the consumer, correspond to a large extent with section $8(1)$ and (2) of the CAA, the two sets of laws also differ in the following respects: in the NCA or in terms of the NCA: (1) the duty is not pertinently imposed for the duration or currency of the credit agreement; (2) the duty is imposed on the consumer only, and not also on a third party who is or was in possession of the goods or who knows where the goods are; (3) the credit provider can request the information orally or in writing, and not just in writing; (4) reference is made to the credit provider only, and not also to a person who can make the request on behalf of the credit provider; (5) on request by the credit provider, the consumer must provide the information in writing (Form 25) or orally, the latter not only if agreed to by the credit provider; (6) on request by the sheriff or messenger, the consumer must provide the information in writing (Form 25) or orally, and not only "verbally"; (7) no time limits or periods are provided for

92 S 65 titled the "Right to receive documents" is clearly not applicable. The fact that the s 97(2) changes must be in writing and delivered is stipulated in the NCA Regulations and not in the Act. S 65(2) pertains to "deliver" in terms of the Act.

93 All these methods constitute safe methods of delivery in respect of which proof can be submitted when required.

94 See heading 21 above.

$95 \mathrm{~S} 97(3)$ of the NCA.

$96 \mathrm{~S} 97(4)$ of the NCA. 
the written or oral notifications by the consumer $;^{97}(8)$ the mode of dispatch of written notifications is not prescribed; ( 9 ) the consumer is not required to notify the person making the request of his or her business and residential addresses; and (10) if at any time under a section 97(3) request the consumer is no longer in possession of the goods, he or she must only provide the name and address of the person to whom possession of the goods has been transferred, without having the alternative duty to provide details of the person to whom the goods were handed over and the additional duty to also inform of the place where the goods are kept.

Before the implications of one or two of the aforementioned differences are discussed, it should be noted that Form 25 (which is a mere restatement of the information that has to be disclosed by the consumer in terms of section $97(3)$ of the NCA) does not take any of the aforementioned matters any further. It should also be pointed out that in terms of both the NCA and the CAA, one of the aspects that must be disclosed by the consumer upon request is the address of the premises where the goods are ordinarily kept and the name and address of the landlord, if any, of the premises. And finally, the authors' comments above in relation to section 97(2), read with regulation $34(1)$ and (2) and Form 24 of the NCA, as compared with section $8(3)$ of the CAA, apply mutatis mutandis and will not be repeated in the discussion that follows.

We submit that saddling only the consumer with the obligation, upon request, to disclose the address of the premises where the goods are ordinarily kept ${ }^{98}-$ and not also a third party who is or was in possession of the goods or who knows where the goods are - in conjunction with requiring only the consumer (who is no longer in possession of the goods), and nobody else, to provide the details of the person to whom possession has been transferred, ${ }^{99}$ materially limits the scope of application and therefore the effectiveness of section 97 of the NCA. The credit provider is for all practical purposes rendered effectively unable to extract information from third parties who may know where the goods are and therefore to track its security successfully. The situation is aggravated by the fact that, in terms of section $97(5)$ of the NCA, only the consumer can be guilty of an offence in relation to section 97 . It is submitted that "transferred" in the context of section 97(4) should be interpreted to mean that possession was "given to" a third party and does not imply that the transfer should have been lawful. Otherwise, a consumer who unlawfully gave a third party possession of goods to which a credit agreement relates would fall outside the ambit of section 97(3) and (4), which would limit the scope of section 97 even further and could never have been the intention of the legislature. Section 97(3) and (4) of the NCA needs to be revisited and aligned with the previous position, where a request for the relevant information could also be made to a third party and where non-compliance by such a third party was also punishable as an offence.

97 E.g., "within 7 days of the receipt of [the] request" or "forthwith by ... verbal information" (see $s$ (2) of the CAA).

98 And the name and address of a landlord, if any, of the premises (s $97(3)$ of the NCA).

99 S $97(4)$ of the NCA. 
We also submit that the effectiveness of section 97(3) and (4) of the NCA is further impeded by the legislature's failure to provide for time limits or periods within which a consumer must respond orally or in writing to a request $^{100}$ and the failure to specify that a written notification must be "delivered" to the person making the request for the information. It can be assumed that these were either oversights by the legislature or that the legislature intended for the reply to follow forthwith or immediately by the consumer by completing Form 25 or by furnishing the information orally. Nevertheless, it is evident that in the absence of a clear indication as to which of the two aforementioned possibilities is the correct one, it may lead to the anomalous situation that failure to comply with section $97(3)$ and (4) cannot be proven because there is no time period within which compliance has to occur. The best solution would probably be to amend regulation 34 to provide for a time period akin to that previously imposed by section 8(2) of the CAA. One could even argue that there is no reason for the information not to be furnished immediately if it is the credit provider making the request, given the opportunity for abuse that a delayed period may occasion. If the lacuna is not resolved, one may surmise that the courts will take the stance that the information should be provided within a "reasonable time" for which they may take guidance from the seven calendar-day period in section 8(3) of the CAA. However, we submit that the current application of section 97(3) and (4) of the NCA is hamstrung by the lack of a time limit for a response in regulation 34 and that this requires legislative intervention.

Notably, neither in section 97, nor elsewhere in the NCA, is it stated that failure to disclose the information per se constitutes an offence - whether unprompted as contemplated in section 97(2), and/or as requested in terms of section 97(3) and (4). However, such failure may become an offence if the circumstances contemplated in section $97(5)(a)$ or $(b)$ are present - namely, if the consumer knowingly provides false or misleading information to a credit provider, sheriff or messenger, or knowingly acts in a manner contrary to section 97 with the intent "to frustrate or impede a credit provider exercising [its] rights under this Act or a credit agreement".

The implication of section $97(5)$ of the NCA is significant: whereas any non-compliance with section $9(3)$ of the HP Act or any non-compliance with section 8 of the CAA constituted an offence, non-compliance with section $97(2)$, (3) or (4) of the NCA only constitutes an offence under very specific circumstances. In order successfully to prosecute a consumer for a contravention of section 97 , there needs to be a clear intent to defraud or mislead the credit provider, sheriff or messenger or to frustrate or impede the credit provider in the exercising of its rights under the NCA or credit agreement and this will have to be proved beyond a reasonable doubt. Section 97 can be contravened in various ways - inter alia, by providing incorrect information or by failing to provide the information as required and, as with section $8(1)$ and (3) of the CAA, section 97 of the NCA creates the possibility that a consumer can be guilty of more than one offence, depending on whether his or her non-compliance relates only to section

100 It should be noted that the empowering provision in the NCA, s 97(3), in contrast to s $97(2)$, states that "the consumer must inform that person, in the prescribed manner and form", and not "in the prescribed time, manner and form". 
97(2) or whether he or she has also failed to comply with a request in terms of section $97(3)$ and (4), where applicable. Accordingly, criminal charges may be pressed either in terms of section $97(5)(a)$ or $(b)$ or both.

However, it is clear that section 97 of the NCA in its current format will be difficult to apply and to prosecute successfully. To illustrate the point: if the consumer, upon request, gives the name and address of a third party to whom possession of the goods has been transferred and the goods were indeed given to the specific third party as stated by the consumer, the consumer has fully complied with the duty imposed by section 97(2). Because the latter subsection does not contain the words "and of the place where they are kept", the duty is fulfilled even where the goods are not kept at the third party's address. Therefore, if a consumer truthfully and completely discloses information, but only as required in terms of section $97(2),(3)$ or (4), he or she will not be guilty of an offence.

\section{CONCLUSION}

Over the years, the legislature has recognised the importance of putting a credit provider, in the context of a credit agreement, in a position to know the whereabouts of both the consumer and the goods financed in terms of the agreement. This information is vital not only for purposes of enforcement of the credit agreement in the event of default by the consumer, or in the event that the consumer unlawfully transfers possession of the goods to a third party, but also for protecting the goods against the inadvertent exercise of the landlord's legal hypothec. The information can also be relevant for jurisdictional purposes. Given that an unlawful misappropriation of goods by a consumer reflects elements of fraud, it is also understandable that noncompliance with the obligation to disclose information regarding the consumer's whereabouts and the location of the goods should be punishable as an offence. It is submitted that this sanction underscores the aim of the NCA in section 3 to create a balanced and sustainable credit market where credit providers are able to keep track of their security. However, the legislature clearly needs to intervene and amend section 97 and regulation 34 of the NCA in the various respects as argued in this contribution, failing which it will be a very limited tool in the hands of a credit provider, who is already hamstrung by all the other procedural hurdles that have been erected by the NCA. Finally, because of the onerous sanction for noncompliance with the provisions of section 97 , it is to be welcomed that the credit agreement must pertinently state the consumer's obligation to disclose the location of the goods as per section 97 of the NCA, and the consequences of a failure to do so.

101 See s 93(2) and (3), read with reg 30 and Form 20.2 and reg 31 of the NCA Regulations respectively. 